\title{
Upplifun barna af leikskóladvöl „Stundum er maður lengi í leikskólanum, en ekki alltaf“
}

Anna Magnea Hreinsdóttir og Kristín Dýrfjörð

Abstract

- Um höfunda

About the authors

- Heimildir

Klukkan mótar starfshætti í leikskólum og stýrir tíma barna í daglegu starfi. Áhrif tímans á leikskólastarf og skipulag pess eru töluverð og er upplifun barna á tíma ekki sú sama og fullorðinna. Klukkan hefur áhrif á barnahópinn og tengist fagmennsku kennara sem felst í skýru dagskipulagi og vel skipulögðu starfi. Á sama tíma getur skipulag tímans komið í veg fyrir flæði í leik barna og dýpt. Markmið pessarar rannsóknar er að leita eftir upplifun barna á dvalartíma sínum í leikskóla og varpa ljósi á hvaða pæettir hafa áhrif par á í peim tilgangi að koma betur til móts við sjónarmið peirra. Rannsakendur byggðu á aðferðum sniðnum að ungum börnum í anda pátttökurannsókna og vörðu tíma með 160 til 180 börnum á aldrinum 4 til 5 ára á níu deildum í sex leikskólum á höfuðborgarsvæðinu. Niðurstöður sýna að leikskólarnir sem tóku pátt í rannsókninni störfuðu eftir hefðbundnu dagskipulagi eða sveigjanlegu, sem pó var í eðli sínu ekki ósvipað hefðbundnu skipulagi, par sem fastir liðir eru matartímar, samverustundir, leikur og útivera. Fram kom að börnin sem rætt var við pekkja ekki annað en að dvelja í leikskóla megnið af vökutíma sínum. Mörg barnanna töldu sig vera lengi í leikskólanum, sumum börnum fannst misjafnt hvort pau eru lengi eða stutt og einhverjum barnanna fannst pau vera stutt 1 i leikskólanum. Fram kom að vinátta barna er peim mikilvæg og að pau fái tækifæri til að fást við fjölbreytt, menntandi og merkingarbær viðfangsefni í leikskólanum sem pau fá að stýra sjálf. Gefa parf tímaskyni barna gaum og ætti skipulag leikskólastarfs að taka mið af upplifun og skynjun barna á tíma.

Efnisorð: Leikskóli, dvalartími barna, starfshættir leikskóla, sjónarmið barna, merkingarbær reynsla

\section{Inngangur}

Umræða um lengd daglegrar viðveru barna í íslenskum leikskólum hefur verið hávær undanfarin ár. Fram hefur komið í erlendum samanburðarrannsóknum að íslensk börn dvelja lengur í leikskólanum en börn í mörgum Evrópulöndum. Börn yngri en priggja ára dvöldu að meðaltali um 37,3 tíma á viku í leikskóla á Íslandi árið 2016, en börn eldri en priggja ára 38,1 tíma á viku. Meðaltal dvalartíma barna í Evrópu var um 28 tímar fyrir báđa hópana og er dvalartími barna á Íslandi pví vel yfir meðaltali í Evrópu (European Commission/EACEA/Eurydice, 2019). Viðvera barna helst í hendur við langan vinnutíma foreldra en atvinnupátttaka foreldra er hvergi eins mikil og á Íslandi og pörf fyrir samastað fyrir ung börn pví einnig mikil (Hagstofa Íslands, e.d.). Á hinn bóginn ber að geta pess að á Íslandi er jafnframt lögð áhersla á að börn eigi rétt á dvöl í góðum leikskólum par sem pau geta notið bernsku sinnar. Pað er í samræmi við rannsóknir sem hafa sýnt að pátttaka barna í leikskólastarfi styður við proska peirra og námsárangur til lengri tíma (European Commission/EACEA/Eurydice, 2019). 
Arna H. Jónsdóttir, Bryndís Garðarsdóttir og Jóhanna Einarsdóttir (2013) gerðu rannsókn á meðal starfsfólks leikskóla og par kemur fram að starfsfólkið telur að börn dvelji almennt of lengi í leikskólanum. Eins og fram er komið er veruleikinn sá, að langflest börn í öllum aldurshópum dvelja par sjö tíma eða lengur. Í pví ljósi æetti að beina sjónum að peim páttum sem taldir eru hafa áhrif á gæði og lífsaðstæður barna pann tíma sem pau eru í leikskóla (Anna Magnea Hreinsdóttir, 2009). Umræða um áhrif langs dvalartíma á félagsproska barna og vellíðan parf að taka mið af hagsmunum barna og leiða til pess að skilningur á pörfum peirra dýpki. Sjónarmið barnanna sjálfra ættu að vega par pungt. Í peirri umræðu parf leikskólinn að vera skilgreindur sem félagslegur vettvangur fyrir börn sem virkra lýðræðislega borgara og fyrsta skólastigið, en ekki sem gæesla (Moss og Cameron, 2020). Rannsóknir hafa verið gerðar á viðhorfum starfsfólks leikskóla og foreldra barna á leikskólaaldri til dvalartíma barna í leikskóla en lítið hefur verið leitað til barnanna sjálfra. Markmið pessarar rannsóknar er að leita eftir upplifun barna á dvalartíma sínum í leikskóla og varpa ljósi á pá pætti sem hafa áhrif par á í peim tilgangi að koma betur til móts við sjónarmið peirra. Er pað í samræmi við 12. grein samnings Sameinuðu pjóðanna um réttindi barnsins sem kveður á um rétt barna til að láta í ljós skoðanir sínar í málum sem pau varða (samningur Sameinuðu pjóðanna um réttindi barnsins, 1992). Minna má á, að upplifun barna á tíma er ekki sú sama og hjá fullorðnum og sýna rannsóknir að upplifun barna á lengd viðveru sinnar í leikskólanum veltur að einhverju leyti á pví sem pau voru að gera yfir daginn. Ef peim fannst skemmtilegt pá var tíminn fljótur að líða og dagurinn stuttur, en ef pau voru að bíða eftir einhverju eða höfðu ekki átt góðan dag að einhverju leyti, pá var tíminn lengi að líða (Anna Magnea Hreinsdóttir, 2009). Áhugavert er að heyra hver viðhorf barna eru til dvalartíma síns í leikskóla og hvaða pættir hafa áhrif par á.

\section{Fræðilegur bakgrunnur}

Fræðilegur bakgrunnur rannsóknarinnar skiptist í umfjöllun um tímann og skynjun barna á honum 1 ljósi kenninga og rannsókna. Gerð er grein fyrir peim áhrifum sem tíminn og skipulag leikskóla geta haft á starf skólans og rætt um rannsóknir sem tengjast vináttu og viðfangsefnum.

\section{Tíminn}

Piaget (1969) leit svo á að pekking barna á tímanum héldist í hendur við vitrænan proska peirra. Fyrsta pekking barna á tíma inniheldur að hans mati einungis einn pátt tíma, tímaröð en ekki heildræna sýn á tíma. Hann taldi að börn pekktu ekki röð athafna sem skipulag og að tíminn væri ekki til í huga ungra barna, eins og fullorðnir pekkja hann, heldur sem hluti af virkni eða hreyfingu. Heidegger (1924/1992, 1927/1962) taldi að tíminn byggði á athöfnum dagsins og að skoða pyrfti hann út frá daglegu lífi. Tíminn væri einungis röð athafna sem ættu sér stað í lífi okkar og gæti liðið hratt eða hægt, allt eftir túlkun okkar á aðstæðum. Dað á sérlega vel við um börn á leikskólaaldri sem oft kunna ekki að mæla tíma eftir klukkunni, heldur fremur eftir pví sem pau eru að fást við (Anna Magnea Hreinsdóttir, 2009; Pacini-Ketchabaw, 2012). Foucault (1977) skoðaði aftur á móti tímann út frá beitingu valds. Hann taldi stjórnun á tíma fólks og að takmarka hann væri ein tegund valdbeitingar og pví væri til dæmis dagskipulag og stundaskrár skóla aga- og valdatæki að hans mati. Bottrill (2018) fjallar um skipulag tímans í leikskólanum og telur pað almennt miðast við parfir starfsfólksins en ekki barnanna. Eitt nærtækasta dæmið er hvernig skipulag í kring um til dæmis kaffi- og matartíma snýst um parfir starfsfólks að hans mati.

Til að átta sig á hvernig tíminn líður er yfirleitt stuðst við staðlaðan tíma, mældan í klukkustundum. Tími hverrar athafnar er mældur í tímaeiningu með klukku, svo sem sekúndum, mínútum, klukkustundum og sólarhringum. Með pví móti er hægt að mæla athafnir og röð peirra á öruggan hátt. Skynjun á tíma (e. sense of time) er bæði getan til að skynja röð athafna, að skipuleggja eigin athafnir og að geta áttað sig á hvernig tíminn líður (e. time-keeping). Eins og Piaget hefur bent á hafa börn á leikskólaaldri oft takmarkaða kunnáttu á klukku og tekur oft langan tíma fyrir pau 
að yfirfæra reynslu sína og pekkingu á tíma yfir á staðlaða mælingu klukkunnar (Harner, 1982; Levin, 1992; Pouthas, 1993). Hve löng er klukkustund? Hvað er hægt að gera á einni klukkustund eða hálfri? Hve lengi á ég að leika mér á pessu valsvæði? Hvað parf ég að gera til að geta verið komin/n út að leika mér eftir hálftíma? Allt eru petta atriði sem börn eiga oft í erfiðleikum með að átta sig á og purfa stuðning fullorðinna til að meta. Af pví leiðir að pegar rannsaka á skynjun barna á tíma er kannski ekki við hæfi að meta hana með klukku. Dað myndi heldur ekki skila miklu að athuga forbekkingu peirra á klukku. Burtséð frá klukkunni getur skynjun á tíma verið ólík eftir pví sem fengist er við (Heidegger, 1924/1992, 1927/1962). Degar tekið er pátt í einhverju ánægjulegu eða nýju, pá pýtur tíminn áfram, en virðist standa í stað pegar lítið er að gerast, eða manni leiðist. Slík skynjun er talin vera óáreiðanleg eða ekki eins áreiðanleg og mæling klukkunnar á tíma. Dað eru einnig tímar, parna mitt á milli, par sem fullri athygli er haldið, en skipulag dagsins pó skynjað. Að ekki sé minnst á hugtakið flæði (e. flow), par sem hægt er að gleyma stað og stund í peirri athöfn sem tekið er pátt í (Csikszentmihalyi, 1990, 1997).

Nomura and Matsuno (2016) hafa rannsakað samskipti og tengsl fólks út frá margradda tíma (e. polyphonic time), en samkvæmt peim skiptist skynjun á tíma í huglægan tíma sem er upplifun á tímanum, hlutlægan tíma sem er mældur eftir klukku, skipulagðan eða hannaðan tíma og gagnvirkan tíma sem á sér stað í samskiptum. Með pessa skiptingu á tíma í huga hafa Katsuura, Ueda og Fujii (2021) rannsakað skynjun kennara á tíma í leik með börnum í leikskóla til að draga fram myndir af upplifun kennarans.

Tími og tímatengsl eru lykilpættir tíma, en einnig lengd og röð athafna (Fraisse, 1963). Dessar grunnvíddir fela í sér önnur hugtök tímans, svo sem fyrir og eftir, meðan, núna og bráđum. Frumskilningur barna á tímabundnum tengslum er mikilvægur og purfa börn að læra að yfirfæra pekkingu sína á tíma og reynslu af athöfnum yfir á klukkustundir og aðrar tímaeiningar (Nelson, 1986; Nelson og Gruendel, 1981). Líklegt pykir að röð atburða gegni mikilvægu hlutverki í tímaskynjun okkar, ekki síður en tímamæling klukkunnar. Рað á sérstaklega við um börn sem hafa enn ekki yfirfært reynslu sína og bekkingu á röð athafna dagsins yfir í mælingu samkvæmt klukkunni. Dað er pví mikilvægt í rannsókn sem pessari að gera ráð fyrir að börn mæli lengd eigin dvalartíma í röð atburða og athafna og upplifun á peim, fremur en í klukkustundum. Í pessari grein er pó hugtakið klukka notað pegar verið er að ræða um pekkingu og upplifun barna á tímaeiningum.

\section{Áhrif skipulags og tíma á leikskólastarf}

Tími er mikilvægur áhrifapáttur í leikskólastarfi og telja James, Jenks og Prout (1998) að lykilatriði í hverri námsskrá sé dagskipulagið eða stundaskráin. Í dagskipulaginu er dagurinn hólfaður niður 1 atburði og athafnir svo sem matartíma, hvíldartíma og leiktíma. Dessar reglubundnu athafnir kortleggja pað sem gerist yfir daginn og staðsetur innihaldið á svæði og tíma. Jenks (2005) telur petta fyrirkomulag hafa annmarka par sem tilvera barna er afmörkuð við daglegt skipulag. Tíminn lýtur klukkunni fremur en einstaklingsbundnum takti barnanna. Dahlberg og Moss (2005) taka undir áhyggjur Jenks af stofnanavæðingu barna sem verja megninu af bernsku sinni í skólum. Munurinn á heimilislífi og daglegu lífi barna í skóla er sá að skipulag og eftirlit er meira í skólanum en heima (van Manen og Levering, 1996). Starfsfólk skóla stjórnar pannig tímasetningu atburða og athafna barna sem leiðir af sér valdaójafnvægi, par sem hægt er að líta á slíkt skipulag tíma sem ákveðna stýringu (Foucault, 1977; James o.fl., 1998). Dví er samrád við börn mikilvægt og aukinn skilningur á hvernig pau upplifa til að mynda daglegt líf í leikskóla í tengslum við lengd pess tíma sem pau dvelja par.

Dagskipulag leikskólans parf að vera sniðið að pörfum barna, proska peirra, aldri og dvalartíma. Mikilvægur liður í daglegum venjum leikskólans er að tekið sé vel á móti börnum og pau kvödd eftir daginn. Dagskipulag getur verið afar ólíkt eftir leikskólum, allt frá pví að vera opið og sveigjanlegt, par sem einu föstu liðirnir eru svefn og hvíldartímar, matartími, leiktími og útivera og yfirí að vera skipulagt frá einum klukkutíma til annars (Mennta- og menningarmálaráđuneytið, 
2011). Athafnir eru skipulagðar í ákveðinni röð, til dæmis morgunmatur, samverustund, frjáls leikur, hópastarf, útivera, hádegismatur, samverustund, útivera, nónhressing, samverustund og frjáls leikur. Athafnirnar eru endurteknar dag eftir dag og viku eftir viku, svo að fátt komi börnunum á óvart og eru pau yfirleitt fljót að átta sig á dagskipulaginu og vita hvað tekur við af hverju (Anna Magnea Hreinsdóttir, 2009; Forman, 2015; Nelson, 1986; Piaget, 1969; Sargent o.fl., 2013; Zacks o.fl., 2007). Börn á leikskólaaldri geta rifjað upp nokkrar athafnir í dagskipulagi leikskóla í réttri tímaröð og skilið tengsl og röð athafna í dagskipulagi, svo sem morgunmat, samverustund og hádegismat (Friedman, 1990). Ljóst er að daglegar venjur og reglur peim tengdar leika hlutverk bæði í félagslegri mótun og tímastjórnun barna í leikskólum. Jafnframt sýna rannsóknir að gildi frjáls leiks er ekki eins áberandi í dagskipulagi leikskóla, prátt fyrir að leikskólakennarar haldi pví á lofti, heldur er leikur gjarnan skipulagður af kennurum sem afmarka honum tíma, rými og viðfangsefni (Markstörm og Halldén, 2009). Uppeldisfræðilegur tími (e. pedagogical time), byggir á daglegum venjum sem taka mið af skynjun barna á tíma með áherslu á takt, vellíðan peirra og nám. Skipulagið parf að miða að pörfum einstaka barns, barnahópa og alls leikskólans. Skipulag tímans parf einnig að endurspegla markmið leikskólastarfs, fjölbreytt viðfangsefni og fjölbreyttan barnahóp. Upplifun barna af leik og tíma tengist vellíðan peirra og áhuga hér og nú (Akita, 2020; Nomura, 2010). Tengsl námsumhverfis, kennarans og barnahópsins endurspeglast í skipulagi tímans og verða merkingarbær í samskiptum, leik og námi (Formosinho og Formosinho, 2016). Pacini-Ketchabaw (2012) hefur rannsakað áhrif klukkunnar á leikskólastarf og telur að áhrif hennar séu töluverð. Hún talar um „ofríki klukkunnar“ og á par við hversu mikið klukkan mótar starfshætti í leikskólum og tíma barna í daglegu starfi. Klukkan hefur áhrif á barnahópinn, starfsfólk og á daglegt skipulag. Hún hefur einnig áhrif á upplifun og skilgreiningu starfsfólks og barna á pví í hverju leikskólastarf felst. Að mati Pacini-Ketchabaw (2012) er klukkan grundvallaratriði í skilningi á leikskólastarfi, skipulagi pess og lögfestingu. Degar börn er farið að lengja eftir pví að komast heim er beim sagt hvenær foreldrarnir koma að sækja, „mamma pín kemur alltaf klukkan fjögur“ - en hvaða pýðingu hefur pað fyrir barn sem veit ekki hvað klukkan er?

Samkvæmt ofangreindu er ljóst að klukkan afmarkar viðfangsefni barna, allt frá móttöku peirra í fataherbergi, matartímum, leiktíma og útiveru til kveðjustundar í lok dags. Klukkan tengist einnig fagmennsku kennara sem felst í skýru dagskipulagi og til dæmis vel skipulögðu hópastarfi og samverustundum. Á sama tíma kemur petta sama skipulag í veg fyrir flæði í leik barna og dýpt (Sara Margrét Ólafsdóttir, 2013). Degar leikskólakennarinn lítur á klukkuna á veggnum og tilkynnir barnahópnum að nú sé kominn tími til að ganga frá eða að fara á salernið fyrir útiveru er kennarinn að staðfesta pað sem er tilhlýðilegt að gera í leikskólastarfi (Pacini-Ketchabaw, 2012). Börnin eru beðin um að drífa sig að klæða sig útiföt, peim finnst sjálfum pau vera dugleg að gera pað og upplifa að pað taki ekki langan tíma. Á sama tíma upplifa leikskólakennarar að börnin séu hæg að klæða sig og taki of langan tíma í að koma sér út að leika (Anna Magnea Hreinsdóttir, 2012). Að fylgja klukkunni er pví mikilvægur liður í viðeigandi starfsháttum í leikskólanum. Á sama tíma má segja að sá kennari sem fylgir ekki klukkunni sé ófaglegur og fylgi ekki viðeigandi starfsháttum.

Að mati Davies og félaga (2013) parf umhverfi leikskóla að vera sveigjanlegt og eiga börn að hafa svigrúm til að sökkva sér (e. incubation time) í leik og skapandi starf án tímapressu. Clark (2020) hefur tengt hugtakið hæg uppeldisfræði (e. slow pedagogy) starfsháttum í leikskólum sem ganga út frá pví að nám eigi sér stað pegar börn fá tækifæri til að sökkva sér niður í áhugaverð viðfangsefni, spyrja spurninga og leita svara við peim. Einnig hefur hugtakið hæg pekking (e. slow knowledge) verið tengt við pað nám sem á sér stað við slíkar aðstæður og snýst um samveru og samtal kennara og barna par sem tíminn er ekki mældur í klukkustundum, heldur í peim tíma og hraða sem börn purfa í námi sínu. Með pví að stilla sig inn á tíma barnanna verða kennarar næmir á námsferil peirra, geta betur stutt börnin og hvatt pau í lausnaleit sinni. Hugtakið felur í sér samtal um nám og starf leikskóla (Clark, 2020). 


\section{Menntandi og merkingarbær reynsla}

Mikilvægt er að skoða hvaða merkingu (e. meaning making) börn leggja í daglegt líf sitt, hvernig pau skilja, túlka og gefa atburðum dagsins, viðfangsefnum og samskiptum merkingu. Detta gera börn í samskiptum sínum við fullorðna og önnur börn. Samkvæmt Bruner (1990) felur nám í sér merkingarbæra reynslu í öllum aðstæðum dagsins, par sem börn eru virkir pátttakendur og reyna að tengja við fyrri reynslu, skilja og leggja vitsmunalega og tilfinningalega merkingu í pað sem fengist er við (Bruner, 1990). Dewey $(1938,1943)$ taldi ekki endilega alla reynslu proskandi eða menntandi. Hann varaði við fánýtum athöfnum sem virðast hafa pað að markmiði að hafa ofan af fyrir börnum á kostnað raunverulegrar pátttöku og áhuga peirra. Hann lagði áherslu á að ekki ætti að leggja fyrir börn verkefni og ætlast til að pau tækju pátt í athöfnum sem ekki fullnægðu pví meginmarkmiði að efla hugsun peirra og proska. Í leikskólum sem er stjórnað af klukku og fyrir fram mótuðum verkefnum er hlutverk leikskólakennara fyrst og fremst að vera sá sem leggur út verkefni og athafnir án pess að tengja pað sérstaklega sérkennum pess umhverfis sem starfað er í eða gæðum pess sem lagt er upp með. Hættan er að börn fjarlægist eigin menningu og umhverfi, pau verði viðtakendur en ekki samskaparar pekkingar (Vintimilla og Pacini-Ketchabaw, 2020). Leikskólareynslan verði par með ekki merkingarbær og afleiðingin pægir en ekki ígrundandi einstaklingar. Eitt af pví sem skiptir máli til að reynsla barna sé bæði menntandi og merkingarbær er hvernig skipulag getur stutt við vináttu og félagsleg samskipti barna. Rannsóknir sýna að vinátta barna, félagar peirra og góð samskipti við pá skipta börn mestu máli (Anna Magnea Hreinsdóttir, 2009, 2012; Corsaro, 2003, 2005; Jóhanna Einarsdóttir og Sara M. Ólafsdóttir, 2020). Vináttan birtist í pví að pau sýna hvert öđru samkennd, deila gleðilegum athöfnum og oft velja pau sér viðfangsefni með hliðsjón af pví hvað félagar peirra kjósa að gera. Einnig sýna niðurstöður rannsókna mikilvægi fjölbreyttra viðfangsefna í leikskólum til að leikur geti verið meginnámsleið barna eins og gert er ráð fyrir í leikskólastarfi (Kristín Karlsdóttir og Anna Magnea Hreinsdóttir, 2016; Mennta- og menningarmálaráduneytið, 2011).

\section{Аðferð}

Rannsóknin byggir á eigindlegum aðferðum, par sem leitast var við að nálgast upplifun barna á eigin dvalartíma í leikskóla. Dannig getur skilningur hinna fullorðnu aukist á pví hvað er börnunum mikilvægt meðan á dvöl peirra stendur og hvernig pau upplifa lengd eigin dvalartíma (Pascal og Bertram, 2009). Rannsóknin byggir á aðferðum sem hafa sérstaklega verið próaðar með sérstöðu ungra barna í huga (Clark og Moss, 2001, 2005). Рað sem parf að hafa í huga varðandi að nálgast sjónarmið barna er að vera sveigjanlegur og næmur á parfir barnanna og að taka sér góðan tíma í verkið (Clark og Moss, 2001). Í samræðum við börnin parf auk pess að huga að pví að hafa viðtalsrammann víðan og gefa börnunum kost á að velja umræðuefnið аð einhverju leyti (Mauthner, 1997). Dannig er stuðlað að valdeflingu barnanna (Clark og Moss, 2001, 2005). Lögð er áhersla á að börn séu virkir pátttakendur raunverulegs könnunarferlis. Aðferðir pátttökurannsókna (e. participatory research) hentuðu pví vel markmiði rannsóknarinnar. Degar pær eru gerðar í samvinnu við börn geta pær veitt innsýn í heim barna og aukið skilning fullorðinna á sjónarmiðum peirra, til að mynda um lengd eigin dvalartíma og hvað gefur dvölinni merkingu. Rannsakendur purfa að gæta pess að ráðskast ekki með börn pegar byggt er á pátttökurannsóknum og að gera ráđstafanir vegna valdaójafnvægs sem skapast milli barna og fullorðinna í rannsóknum (Graue og Walsh, 1998; Groundwater-Smith, Dockett og Bottrell, 2015).

Rannsóknarspurningin sem leiddi rannsóknina var: Hver er upplifun barnanna á dvöl sinni og lengd eigin dvalartíma i leikskólanum?

Til að nálgast rannsóknarefnið voru börn spurð um ýmislegt sem tengist klukku, tímaskyni og upplifun á tímalengd atburða, en einnig um hvað skapaði merkingu fyrir pau í leikskólanum, t.d. hvað tæki stuttan tíma og hvað langan? 


\section{Pátttakendur og vettvangur}

Rannsóknin fór fram á níu deildum í sex leikskólum. Valdir voru leikskólar í nokkrum sveitarfélögum á höfuðborgarsvæðinu, peir voru ólíkir að stærð og gerð og byggðu starf sitt á ólíkri hugmyndafræði. Var pað gert til að fá breidd í rannsóknina. Rannsóknin fór fram á elstu deild leikskólanna, par sem oft voru bæði fjögurra og fimm ára börn. Ekki er gerð frekari grein fyrir leikskólunum að öðru leyti. Öllum börnunum á deildinni, sem fengu upplýst sampykki frá foreldrum sínum, var boðið að taka pátt í rannsókninni. Leikskólastjórar og deildarstjórar báru ábyrgð á að afla upplýsts sampykkis frá foreldrum sem í öllum tilfellum var auðfengið. Alls dvöldu rannsakendur með um 160 til 180 börnum.

\section{Framkvæmd og gagnaöflun}

Tveir rannsakendur skiptu með sér gagnaöflun sem fólst í að heimsækja, kynnast starfinu og í fyrstu heimsókn skoða dagskipulag viðkomandi leikskóla með pað að markmiði að kynnast leikskólanum og velja tíma til gagnaöflunar. Hver leikskóli var heimsóttur tvisvar til prisvar sinnum (ef fleiri en ein deild var heimsótt). Rætt var við stjórnendur og síðan vörðu rannsakendur tveimur til premur klukkutímum með börnum á deild, kynntu sig og sögðu frá hvað peir væru að gera - að vita hvað börn gera í leikskólum. Síðan tóku peir pátt í peim athöfnum sem par fóru fram. Í flestum tilfellum voru rannsakendur mættir um klukkan níu og fylgdu börnunum fram að hádegismat. Nýttu peir pau tækifæri sem gáfust í leik til að spyrja pau börn sem gáfu færi á samtali um dvöl peirra í leikskólanum. Á pann hátt gátu börnin jafnóðum gefið upplýst sampykki sitt fyrir samtalinu og hafnað pátttöku með pví að slíta samtali. Börnin voru ekki spurð að nafni og öll gögnin eru hreinsuð af peirra eigin nöfnum. Börnin voru forvitin um rannsakendur og fannst yfirleitt ánægjulegt að spjalla um daglegt líf í leikskólanum. Eins og fram er komið var stuðst við viðtalsramma með spurningum sem tengdust rannsóknarspurningunni um lengd eigin dvalartíma, dagskipulagið og pau viðfangsefni sem börnunum fundust skemmtilegust og leiðinlegust, erfiðust og best. Er pað í samræmi við pær aðferðir sem heppilegt er að styðjast við til að nálgast sjónarmið barna (Clark og Moss, 2001, 2005).

Rannsakendur höfðu með sér liti og blöð sem börnunum fannst oft spennandi að fá að prófa. Gáfu teikningarnar frekari innsýn í upplifun peirra af pví sem pau ræddu um. Teikningar geta verið góð leið fyrir börnin til að tjá sig um viðkomandi viðfangsefni og skerpa athygli peirra. Dær gera einnig hugmyndir barna sýnilegri (Clark og Moss, 2001, 2005; MacNaughton o.fl., 2010; Mauthner, 1997). Dæmi um pað eru teikningar barnanna í pessari rannsókn af klukkum (sjá Mynd 5, 6 og 7). Teikningarnar voru ekki greindar sérstaklega, en vörpuðu ljósi á hugmyndir barnanna og á ýmislegt í daglegu lífi peirra í leikskólanum. Teikningarnar gerðu andrúmsloftið 1́ viðtölunum afslappaðra og höfðu börnin eitthvað fyrir stafni meðan á umræðum stóð. Samræðurnar voru hljóðritaðar, afritaðar og notaðar til frekari greiningar. Pegar gögnum er safnað á pann hátt sem hér er gert, geta pau virst brotakennd. Hins vegar má benda á að pau sýna líka ákveðið mynstur sem sýnilegt er á milli mismunandi leikskóla og hugmyndafræði (Clark og Moss, 2001, 2005). Rannsakendur báđu ekki um leyfi fyrir að taka ljósmyndir af börnum meðan á heimsókn stóð (utan peirra sem teknar voru af teikningum og skipulagi á veggjum), en eftir á að hyggja hefði pað verið gott til að getað stutt gagnagreiningu með ljósmyndum sem til dæmis sýndu börnin teikna.

\section{Gagnagreining}

Demagreining var notuð til pess að greina samtölin við börnin. Rannsakendur greindu gögnin fyrst hvor í sínu lagi og síðan saman í pví augnamiði að auka trúverðugleika rannsóknarinnar (Groundwater-Smith o.fl., 2015). Eftir hverja leikskólaheimsókn hittust rannsakendur, ræddu og greindu heimsóknirnar og lögðu drög að próun rannsóknarinnar og næstu skrefum. Deir ræddu раð sem stóð upp úr að peirra mati, gerðu tilraun til að túlka eigin upplifun og lögðu pannig 
drög að síðari pemagreiningu. Til dæmis kom fljótlega fram í samtölum rannsakenda að peir sáu og upplifðu mismunandi dagskipulag sem vakti forvitni um hvort hægt væri að skoða gögnin af sjónarhóli dagskipulags. Gögnin voru afrituð, kóðuð og flokkuð og pemu fundin. Demun sem fram komu fjölluðu um dagskipulag, tímann og klukku, upplifun barnanna á lengd dvalartíma, vináttu barnanna og viðfangsefnin í leikskólanum.

\section{Siðferðileg atriði}

Rannsóknum með börnum fylgja fjölmörg siðferðileg álitamál sem mikilvægt er að hafa í huga (Anna Elísa Hreiðarsdóttir og Kristín Dýrfjörð, 2019; Anna Magnea Hreinsdóttir, 2012; Clark og Moss, 2001, 2005; Groundwater-Smith o.fl., 2015; Guðrún Kristinsdóttir, 2017; Guðrún Kristinsdóttir og Hervör Alma Árnadóttir, 2015; Wood, 2018). Rannsakendur gerðu sér grein fyrir pví valdaójafnvægi sem ríkir milli barna og fullorðinna og leituðust við að draga úr pví, meðal annars með pví að fara á vettvang barnanna, í leikskólann, par sem börnin voru á sínum heimavelli (Graue og Walsh, 1998; Jóhanna Einarsdóttir, 2008). Lögð var áhersla á að rannsakendur væru forvitnir og áhugasamir gestir barnanna og á að fá fram fjölbreyttar skoðanir barnanna á dvalartíma sínum í leikskólanum og daglegum athöfnum, en samtímis verður að taka fram að aðferðin býður ekki upp á djúpar samræður (Graue og Walsh, 1998) og pví hætta á brotakenndum gögnum.

Sampykki fékkst frá rekstraraðilum, leikskólastjóra, starfsfólki deildarinnar sem rannsóknin fór fram á, foreldrum barnanna á deildinni og frá börnunum sjálfum jafnóðum og talað var við pau (Groundwater-Smith o.fl., 2015). Degar rannsóknin var útskýrð fyrir börnunum var peim sagt í einföldu máli um hvað hún snerist og hvert hlutverk peirra væri, og auk pess var peim gerð grein fyrir pví að pau gætu hætt pátttöku hvenær sem væri (Clark og Moss, 2001, 2005; Guðrún Kristinsdóttir, 2017; Wood, 2018). Leikskólarnir eru ekki nefndir á nafn, peim ekki lýst og dulnefni eru notuð í staðinn fyrir rétt nöfn leikskóla og barnanna. Er pað gert til að tryggja nafnleynd og í samræmi við markmið rannsóknarinnar, sem var að varpa ljósi á upplifun barna á dvöl sinni í leikskóla.

Alison Clark, einn höfundur mósaík-nálgunarinnar, var ráđgjafi rannsakenda og aðstoðaði við undirbúning hennar og úrvinnslu. Sambærileg rannsókn var einnig unnin við Háskólann í Zagreb, Króatíu undir stjórn Adrijana Višnjić-Jevtić. Rannsóknin fékk jákvæða umsögn Siðanefndar háskólanna um vísindarannsóknir.

Rannsóknin var styrkt af Rannsóknasjódi Háskóla Íslands (University of Iceland Research Fund).

\section{Niðurstöður}

Niðurstöður eru settar fram eftir peim pemum sem fram komu í samtölum við börnin. Rætt var um dagskipulagið og daglegar athafnir. Einnig var ræett um skilning barnanna á klukku og tíma, ásamt upplifun peirra á lengd eigin dvalartíma í leikskólanum. Vinátta kom til tals sem og viðfangsefni dagsins.

\section{Dagskipulag}

Í vettvangsheimsóknum og við skoðun á dagskipulagi leikskólanna varð ljóst að dagskipulagi má í grunninn skipta í tvennt, annars vegar par sem aðallega hefðbundin sýnileg skipting var á milli atriða í skipulaginu (sjá til dæmis Mynd 1 og 2) og svo pað sem kalla má flæðandi skipulag par sem meira frelsi og færri atriði voru skipulögð yfir daginn. Einhverjir leikskólar falla svo par á milli, með blöndu af hefðbundnu og flæðandi skipulagi. Skipulagið tók pá til meginatriða eins og matartíma, samveru, hópastarfs og frjáls leiks. 


\section{Hefðbundið skipulag}

Skipulag leikskólanna sýndi að dagurinn einkennist af athöfnum sem taka við hver af annarri. Í leikskólunum voru atriðin á skipulagi frá 13 til 19 talsins. Dæmi um slíkt mátti sjá í að minnsta kosti tveimur leikskólanna (sjá Mynd 1 og 2).

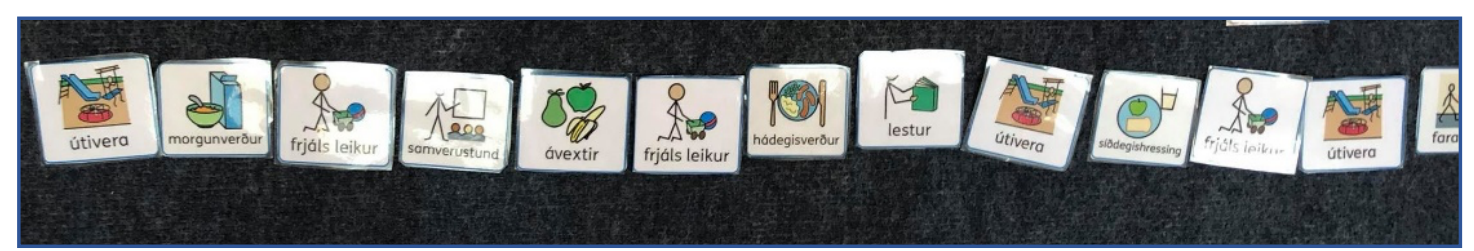

Mynd 1. Dagskipulag leikskólans Sumarvellir.

Eins og sjá má á Mynd 1 voru 13 athafnir skipulagðar daginn sem rannsakandi dvaldi í leikskólanum. Börnin hófu daginn úti en fóru fljótlega inn í morgunmat. Eftir morgunmatinn var tími til að leika sér. Samverustund tók síðan við par sem meðal annars var farið yfir athafnir dagsins, veðrið, heppilegan klæðnað fyrir börnin 1 útiveru og annað sem bar hæst pennan dag. Í samverustundinni fengu börnin ávaxtabita, lesið var fyrir pau, sagðar sögur og sungið. Eftir samverustundina gátu börnin valið sér leiksvæði og leikfélaga par til komið var að hádegisverði. Eftir hádegisverðinn var lesið áđur en börnin héldu í útiveru. Eftir útiveru var síðdegishressing, pví næst frjáls leikur inni og að lokum útivera par til foreldrar komu að sækja börnin. Upphaf og lok dagskipulagsins litaðist að einhverju leyti af breyttu verklagi vegna COVID-19 faraldursins.

Í samverustundinni um morguninn skiptust börnin á að segja barnahópnum frá fyrirkomulagi dagsins. Sigrún sagði frá á eftirfarandi hátt:

Við förum út 1 smá stund og svo inn að borða morgunmat. Svo förum við í frjálsan leik, pað er stutt, svo förum við í samverustund og svo förum við út.

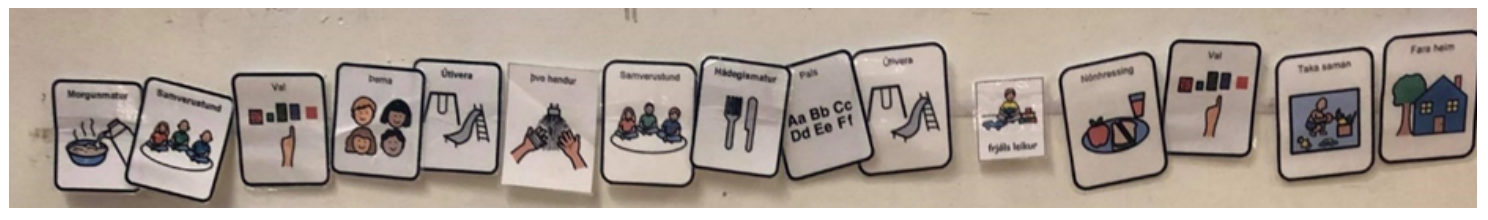

Mynd 2. Dagskipulag leikskólans Haustvellir.

Í öðrum leikskóla var dagskipulagið sambærilegt, sjá Mynd 2. Par voru 15 athafnir skipulagðar daginn sem rannsakandi dvaldi í leikskólanum. Par var komið að Lóu að segja barnahópnum frá atburðum dagsins:

Lóa: ... „pað vantar hádegismatinn.“

Kennari: ... , ,pað vantar hádegismatinn. Dið eruð alveg með petta á hreinu. Ég var alveg að gleyma mér. Lóa ætlar að fara yfir dagskipulagið með okkur.“

Lóa: „Morgunmatur, samvera, val, pemahópur, fara út, pvo hendur, fara í samveru, hádegismatur, Pals, leika og fara út, nónhressing, fara í val, ganga frá og fara svo heim.“

Lóa: „Рað er fimmtudagur í dag, nei, priðjudagur.“

Eftir samverustund í einum leikskóla teiknuðu börnin dagskipulagið á löng blöð, sjá Mynd 3 og 4. 


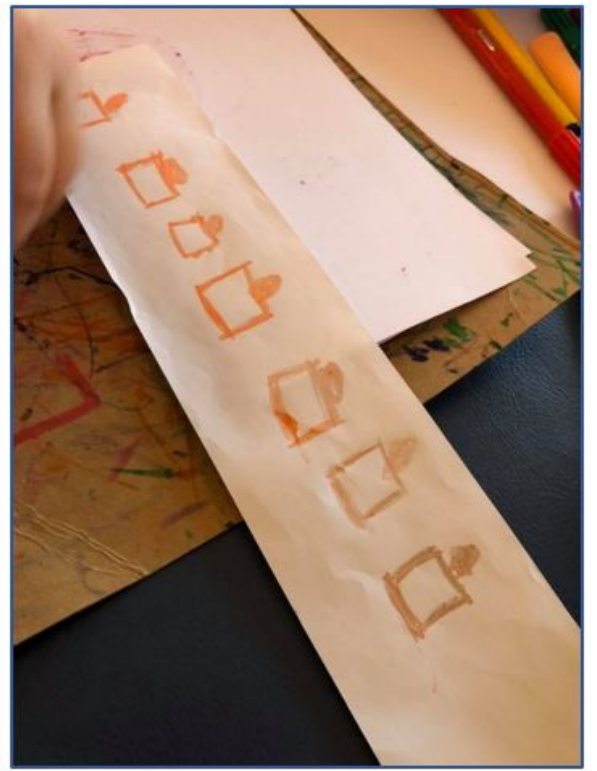

Mynd 3. Dóra teiknaði atburði dagsins, sem síðar breyttust í pakka

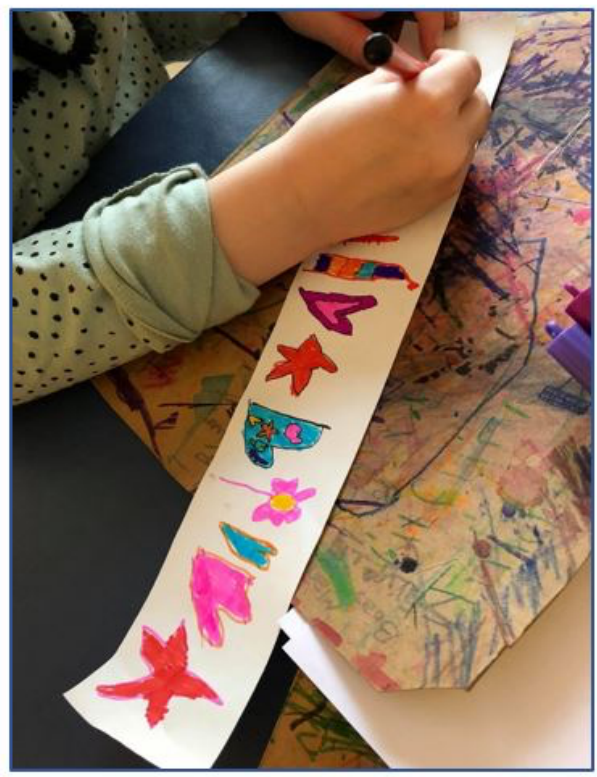

Mynd 4. Ásta teiknaði atburði sem urðu að̃ blómum, hjörtum og stjörnum

\section{Flæðandi skipulag}

Finna mátti dæmi um flæðandi skipulag par sem færri atriði voru skipulögð yfir daginn, sjá Mynd 5. Par virtust börnin hafa meira frelsi til að velja athafnir og röð peirra. Dæmi voru um flæðandi matartíma sem fólust í að börnin gátu sjálf kosið hvenær pau vildu borða meðan á matartímanum stóð. Pau börn sem ekki voru að borða hverju sinni gátu pá haldið áfram í leik með félögum sínum inni á deildum.

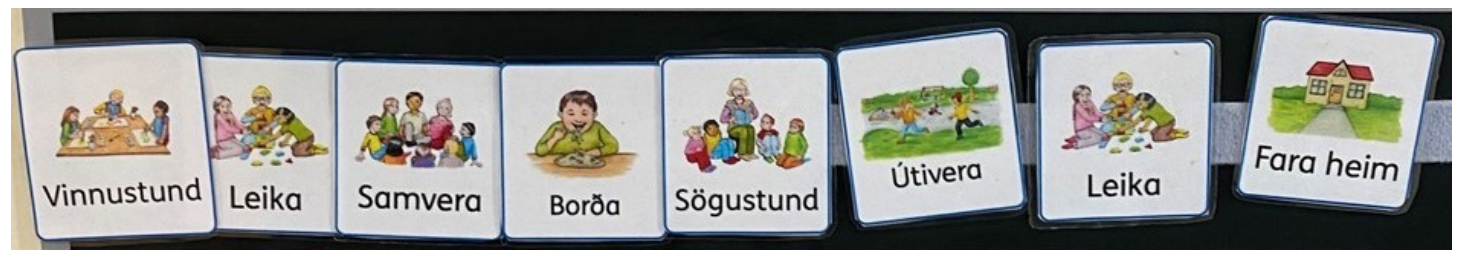

Mynd 5. Dagskipulag leikskólans Vorvellir.

Í leikskóla par sem er flæði í skipulaginu átti eftirfarandi samtal sér stað. Rúnar sagði:

Degar ég kem í leikskólann byrja ég að leika mér. Svo fer ég að borða, pá fer maður að leika aftur, svo samverustund og stundum út, og svo inn og út.

Spurður að pví hvað væri skemmtilegast að gera svaraði Rúnar: „Mest gaman er að leika í pessum kubbunum“" [benti á hornið með einingakubbum].

Rannsakandi spurði: „Ef maður er að leika í einingakubbunum er tíminn pá lengi eða fljótur að líða?“"Eftir smá umhugsun svaraði Rúnar: „Lengi.“

Fram kom að börnin geta valið að leika hvenær sem er í kubbum. Rúnar sagði: „Maður má leika hvenær sem er.“ Að hans mati var jafn gaman að byrja einn að leika og leika með vini í kubbunum.

Rúnar færði sig frá rannsakanda yfir á kubbasvæðið og byrjaði að byggja einn, eftir smá stund bættust fleiri börn við og úr varð samleikur. 
Í öðrum leikskóla með flæðandi skipulag sagði Halldór rannsakanda frá atburðum dagsins á pennan hátt:

Við fáum morgunmat í leikskólanum, svo göngum við frá og förum að leika og svo er samvera og svo förum við að leika eða út eftir samveruna. Svo pegar við erum búin að vera úti pá er matur og svo hvíld og svo aftur að leika.

Í leikskóla sem byggði á flæðandi skipulagi spurði rannsakandi hvað væri gert í leikskólanum. Nokkur börn svöruðu í kór. „Lita, leika, leika, leika, spila.“

Elfar var spurður að pví hvað hann gerði pegar hann kæmi í leikskólann. „Ég finn mér eitthvað að gera.“ Inntur nákvæmar eftir pá nefndi hann sem dæmi að spila og tefla.

\section{Klukkan og tíminn}

Dar sem skipulag leikskóla markast að miklu leyti af klukkunni voru börnin spurð spurninga varðandi klukku. Spurð að pví til hvers klukka er notuð svaraði Anna: „Til að vita hvað maður er lengi í skólanum, leikskólanum eða vinnunni.“”

Dóra og Ásta fóru að syngja saman pegar pær heyrðu minnst á klukkuna:

Tíminn líður, títt og ótt,

Tifar klukkan dag og nótt.

Jörðin snýst. Eins pað er,

árið líka hringinn fer.

TIKK, TAKK, TIKK, TAKK.

Í samræðum í öðrum leikskóla var umræða meðal barnanna um hversu langan tíma pað tæki að syngja:

Jóhann sagði: „Við erum rosalega lengi að syngja.“

Rúnar svaraði: „Við erum lengi að syngja fótboltalagið.“

Sigríður svaraði: ,Já, og matarlagið.“

Jóhann bætti við: „Við erum tuttugu, áttatíu að syngja.“

Eftirfarandi samræða átti sér stað í frjálsum leik. Börnin vildu syngja uppáhaldslagið sitt fyrir rannsakanda, en hann kannaðist ekki við pað. Jón sagði pá að kennarinn peirra hefði kennt peim pað á porranum [viðtal tekið á porra]. Aðspurð um hvenær porrinn væri, svaraði Jón fyrir hópinn: „Við vitum pað ekki.“

Börnin voru spurð hvort pau kynnu á klukku eða gætu teiknað klukku. Sigurður sagðist kunna á klukku og eiga klukku. Magnús sagðist einnig kunna á klukku. Sigurður sagðist geta teiknað klukku en ekki teiknað stafina. 


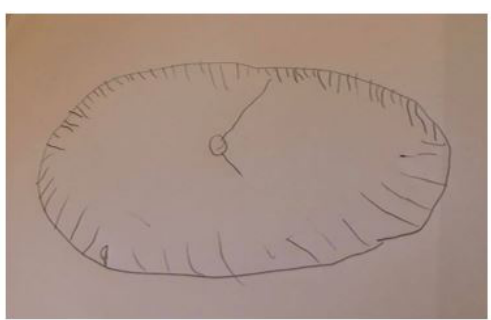

Mynd 1

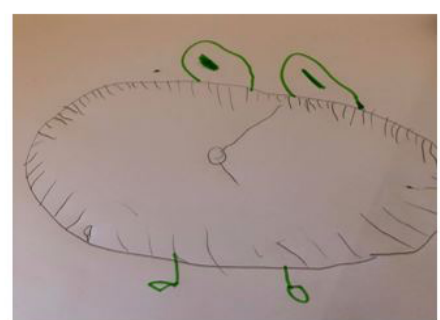

Mynd 2

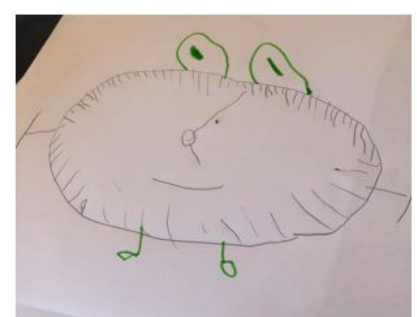

Mynd 3

Mynd 6. Klukka teiknuð.

Sigurður teiknaði klukku, sjá Mynd 6.1. Magnús vinur hans bætti fótum og augum á klukkuna, sjá Mynd 6.2. Sigurður bætti höndum og munni á klukkuna svo að klukkan gæti sagt hvað hún er, sjá Mynd 6.3.

Sigurður taldi strikin á klukkunni upp að 18 og sagði að klukkan ætti að vera í eldhúsinu hans heima. Sigurður og Magnús töldu saman strikin á klukkunni:

Hérna er einn og hérna fjórir, hérna er sex og hérna er sjö, átta, níu, ellefu, prettán, fjórtán, fimmtán, sextán, sautján, átján, tuttugu, níutíu, hún er níutíu, hún er tuttugu og átta.

Í öđrum leikskóla fór einnig fram umræða um klukkuna. Tvær stúlkur sögðust ekki kunna á klukku en buðust til að teikna klukku, sjá Mynd 7 og 8.

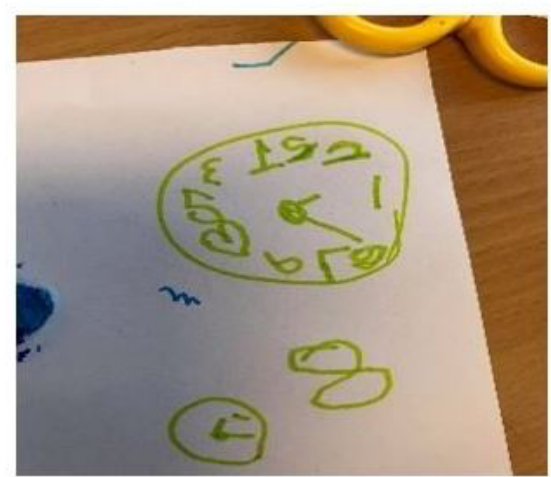

Mynd 7 Klukka sem Dóra teiknaði

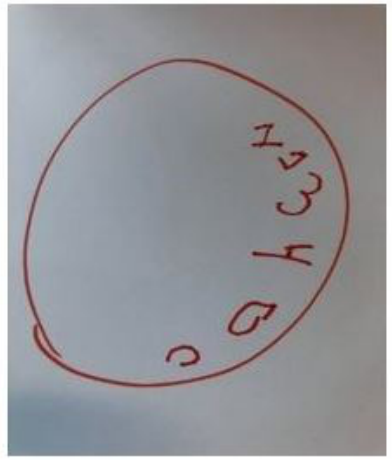

Mynd 8 Margrét teiknaði stóra klukku og stafi

Í einum leikskóla fara börn í ferðir út fyrir leikskólann, pau sögðu pær geta bæði verið langar og stuttar. Degar pau voru beðin um að nefna dæmi sagði Árni: „Stundum bara stutt, en stundum förum við allan daginn. Við fórum í Viðey, og pá vorum við bara svona fimm klukkutíma.“

Á sama leikskóla spurði rannsakandi hvort börnin pyrftu stundum að bíða.

„Já, í korter,“ sagði Dagný.

Hrund bætti við: „Í hálftíma.“

Og Sigrún sagði: „Í klukkutíma.“

Rannsakandi: „Eftir hverju eruð pið pá að bíða?“

Sigrún: ,Já, kannski strætó.“

Í einum leikskóla teiknaði Elfa leiksvið og skrifaði efst „Velkomin í leikhúsið.“

Rannsakandi spurði: „Finnst pér gaman að fara í leikhús?“

Elfa: „Nei, pví pá parf ég að sitja hljóðlát í svona klukkutíma.“ 


\section{Upplifun barna á eigin dvalartíma}

Pau börn sem tjáðu sig um lengd eigin dvalartíma höfðu skiptar skoðanir á hversu langur hann var. Sumum börnum fannst pau vera lengi í leikskólanum, öðrum börnum fannst vera misjafnt hvort pau væru lengi eða stutt og einhverjum börnum fannst pau vera stutt í leikskólanum.

Hér eru dæmi um svör um lengd eigin dvalar í leikskólanum:

Dóra: „Ég kem á undan öllum í leikskólanum, en fer stundum snemma, en stundum ekki snemma."

Ásta: „Mér finnst tíminn lengi að líða í leikskólanum.“

Sigurður sagði: „Ég er búinn að vera lengi í leikskólanum pegar pabbi sækir mig.“

Stefán: „Ég er lengi í leikskólanum, ég veit ekki hvenær ég er sóttur.“

Kristín: „Ég parf stundum að bíða lengi í leikskólanum pegar mamma er lengi að sækja mig."

Davíð sagði: „Ég er lengi í leikskólanum og pað er rosalega langt síðan ég var bara stuttan leikskóla.“

Sum börnin svöruðu spurningunni á pann hátt að peim fannst pau stundum vera lengi og stundum stutt. Hér eru dæmi um slík svör:

Unnar sagði: „Degar ég er að leika úti, pá er ég lengi, en pegar ég er að leika inni, pá er ég stutt."

Sigrún sagði: „Stundum er maður lengi í leikskólanum, en ekki alltaf.“

Einar sagði: „En ef maður er í legó eða einhverjum dótaleik, pá er maður oftast mjög lengi.“

Halldór sagði: „Klukkan er tólf pegar ég kem og hundrað pegar ég er sóttur eða fimmtán.“

Gyða sagði: „Stundum er maður stutt í leikskólanum, pá er maður oftast stutt að borða.“

Í öđrum leikskóla svaraði Jóna að ef hún væri stutt í leikskólanum væri hún sótt pegar hún væri búin að borða hádegismatinn. Börnin höfðu skýringu á bví af hverju pau voru stutt í leikskólanum. Dá voru pau sótt til að fara í afmæli, jarðarför eða í búðina. Spurð að pví hvað pau myndu gera ef pau væru sótt snemma sagði Davíð að hann myndi fara í Húsdýragarðinn og Sigrún sagðist pá fara í Partýbúðina að kaupa búning fyrir öskudaginn.

Ljóst er að börn upplifa á ólíkan hátt hvort athafnir eða pættir í skipulagi dagsins taki langan tíma eða stuttan. Dæmi var pegar börnum fannst pau stutt í útiveru en lengi í matartíma í einum leikskólanum. Par sögðu börnin líka að pað sem væri gaman tæki stuttan tíma, en pað sem peim pætti leiðinlegt væri lengi að líða. Pegar pau voru spurð um hópatíma, hvort pau væru lengi eða stutt, var svarið lengi. Hins vegar sögðu pau líka að peim pætti pau lengi í kubbum, en par sem pau skiptust á par, væri pað samt stutt.

Sigrún sagði að börnin væru ,stutt“ að klæða sig. „,Sumir eru mjög fljótir líka í pollagallann. Við förum í leikskólastund fyrst og svo að borða og svo að lesa og svo að leika.“

Í einum leikskóla var umræða meðal barna um tafl og hvort pað tæki langan eða stuttan tíma að tefla. Ægir svaraði að pað tæki stundum langan og stundum stuttan tíma. Til dæmis pegar hann tefldi á móti Garðari tæki pað stuttan tíma, af pví að Garðar kynni ekki mannganginn nógu vel. 


\section{Merkingarbær og menntandi reynsla}

Vináttuna bar á góma hjá börnunum í samtölum peirra á milli og við rannsakanda. Sögðust börnin eiga marga vini í leikskólanum, „hundrað vini, fullt af vinkonum, ekki bara eina.“ Pau sögðust eiga „mjög marga vini í leikskólanum, fimmtíu eða milljón.“ Deim fannst mörgum skemmtilegast að leika við vini sína og að peir væru alltaf góðir. Sumum börnum fannst erfiðast í leikskólanum ef einhver var að meiða og bíta og klípa. Sigríður teiknaði mynd af sér glaða að sjá (sjá Mynd 9) og sagði: „Рað vondasta í leikskólanum er að kýla og að bíta.“

Í einum leikskóla svaraði Arna: „Mér finnst skemmtilegast að vera í útiveru, að róla.“ Fram kom að Arna átti vin á deildinni sem er yngri en hún og var í hópastarfi pegar frjáls leikur var hjá hennar hóp. Dví var hún að bíða eftir að hitta vin sinn í útiveru.

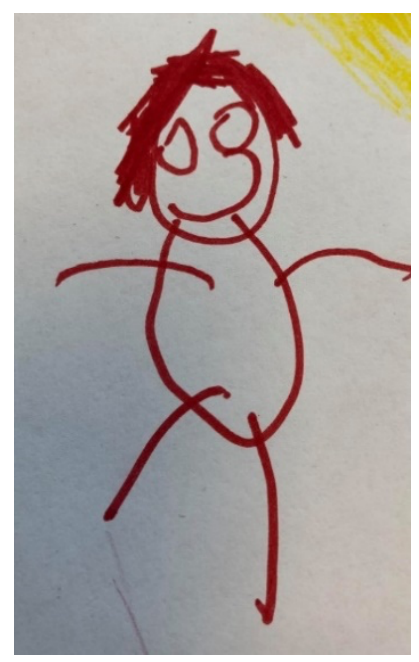

Mynd 9. Ég glöð í leikskólanum sjálfsmynd Sigríðar.
Börnin voru spurð að pví hvað væri skemmtilegast að gera í leikskólanum eða best. Svörin voru einstaklingsbundin og oft tengd pví sem börnin voru að fást við pann daginn. Mörg barnanna sögðu að allt væri skemmtilegt í leikskólanum og að pað væri allt gaman par:

Sigrún: „Mér finnst rosa gaman að lita.“

Sigurður: „Баð er skemmtilegt að leika með villidýrin ljón og tígrisdýr."“

Árni sagði; „Náttúrulega að vefa og spila.“

Ægir vinur Árna bætti við: „,Og spila fótbolta.“

Alls kyns kubbaleikir voru einnig skemmtilegir. Jóni fannst skemmtilegt að leika í holukubbunum, en fannst svolítið erfitt að ganga frá peim, peir eru svo stórir og margir, sjá Mynd 10. Hann sagði að börnin byggju til hús og rennibraut úr kubbunum.

Halldóri fannst best að leika með holukubbana ef pað voru margir holukubbar, „,rosalega margir“. Svo fannst honum gaman að leika með dúpló, stafakubba, segulkubba og nýju segulkubbana.

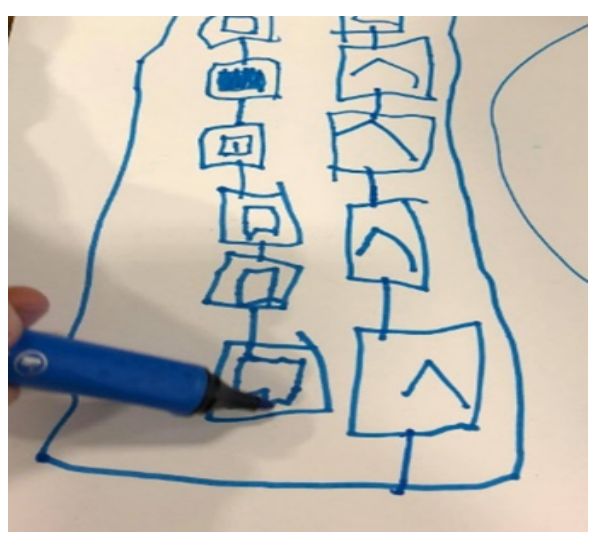

Mynd 10. Halldór teiknaði marga holukubba.
Dað er starfræktur kór í einum leikskóla sem börnin voru sammála um að væri skemmtilegt að taka pátt í. Par syngja pau og pað fannst peim pað mjög gaman.

Á einum stað kom fram að börnin teikna mikið og teikna hvert fyrir annað, á pessum tíma var mikið teiknað af hjörtum og regnbogum. „Við teiknum fyrir hvor aðra,“ var sagt.

Í öðrum leikskóla voru nokkrar stúlkur nýkomnar úr leik með Barbiedúkkur og fannst pað skemmtilegt. Par var líka hafmeyju Barbiedúkka sem vakti lukku, sjá Mynd 11. 


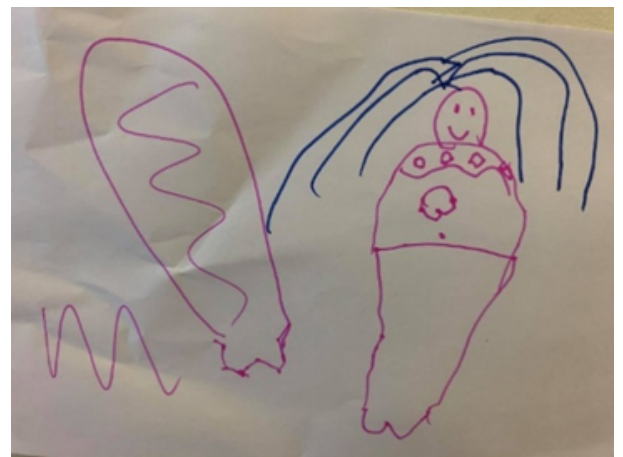

Mynd 11. Hafmeyju Barbie leikur í leikskólanum.
Í einum leikskóla voru börnin að koma inn eftir útiveru. Í útiverunni hafði drengjahópur verið að drullumalla. Deim fannst mjög gaman að vera úti og drullumalla. Ein stúlkan hafði orð á pví að peir mættu pað ekki. Drengirnir voru ekki sammála pví, par sem kennarinn hafði ekki sagt peim pað.

Telma sagði að sér fyndist ekki gaman úti, strákunum fannst gaman úti sagði hún ,af pví að peir voru að drullumalla og veistu hvað peir voru að gera, peir voru að setja drullumall á gangstéttina." Hún sagði: „Við (stelpurnar) vorum að reyna að hreinsa pað og ég saknaði Maríu ömmu minnar og ég saknaði ömmu minnar og afa.“

Börnunum fannst gaman úti, nema ekki pegar pau voru of lengi úti „,pá verður mér kalt“ eins og Stefán orðaði pað. Telma sagði að henni fyndist leiðinlegast að leika úti „af pví að ég elska ekki rigningu“. Фað sem börnin töldu skemmtilegast að gera úti var að klifra upp á pak, að vera

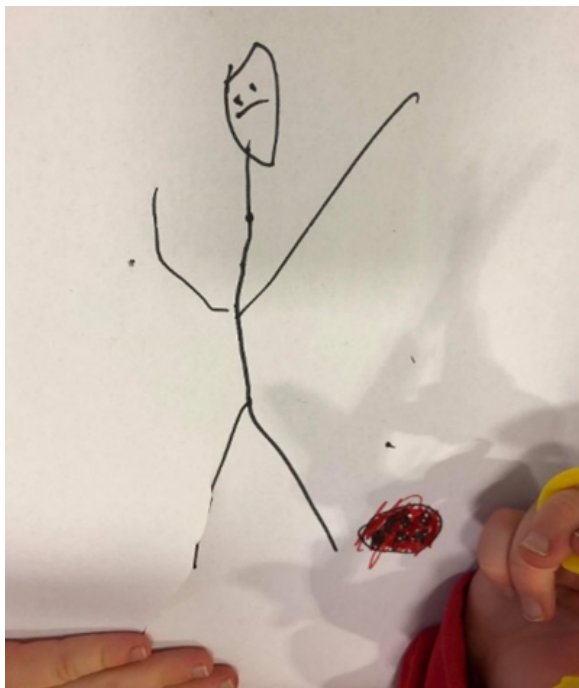

Mynd 12. Kristján teiknaði sjálfan sig spila fótbolta úti. í fótbolta, (sjá Mynd 12), og að fara í gönguferðir, nema pegar purfti að labba langt.

Einnig rifjuðu börnin upp eitthvað sem var ánægjulegt og eftirminnilegt.

Sigrún: „Að fá okkur ís um jólin í leikskólanum.“

Stefaníu fannst leiðinlegast pegar hún var ekki í leikskólanum.

Söndru fannst til dæmis erfiðast að búa til fiðrildi. Dögg fannst pað ekkert erfitt, en pær höfðu báðar verið að búa til fiðrildi í jólagjöf handa foreldrum sínum. Dögg sagðist hafa gert bangsa og „,pað var fiskur á maganum á honum. Pabbi fékk bangsann en mamma fékk fiðrildið sem var með blómunum í jólagjöf.“

Á einum stað var Gunnur að teikna dagatal fyrir mömmu sína. Degar hún lýsti pví var pað svipað og jóladagatölin, opna einn glugga í einu. „Svo opnar maður einn í einu, fyrst á maður að opna sem stendur einn og svo næsta dag sem stendur tveir og næsta dag sem stendur prír. Svo opnar maður og litar inn í pað hvað maður er.“ Spurð hvað henni fyndist skemmtilegast að gera í leikskólanum, svaraði Gunnur: „Mér finnst skemmtilegast að gera dagatal.“

Sumum börnum fannst hvíldin leiðinleg, af pví að pau vildu vaka. Önnur nefndu samverustundina. Nokkur börn nefndu pað аð perla sem leiðinlegasta viðfangsefnið. Sum barnanna töluðu um að pað væri erfitt að vinna verkefnin. Önnur nefndu að pað væri leiðinlegast ef einhver meiddi sig eða væri að gráta. Í einum leikskóla nefndu tvær stúlkur að pær vildu heldur vera heima að „chilla“ en að vera í leikskólanum, jafnvel hanga bara í rúminu og gera ekki neitt. 


\section{Umræður og lokaorð}

Hér hefur verið fjallað um rannsókn sem fram fór á níu deildum í sex leikskólum á höfuðborgarsvæðinu. Pær lýsa sjónarmiðum peirra barna sem rætt var við á peim tíma sem rannsóknin stóð yfir. Markmið pessarar rannsóknar er að leita eftir upplifun barna á dvalartíma sínum í leikskóla og varpa ljósi á hvaða pættir hafa áhrif par á í peim tilgangi að koma betur til móts við sjónarmið peirra.

Hver er upplifun barnanna á dvöl sinni og lengd eigin dvalartíma í leikskólanum var spurningin sem lagt var upp með. Samkvæmt niðurstöðum er pað mjög einstaklingsbundið. Ljóst er að flest börnin átta sig vel á röð atburða og hafa tímaskyn sem tengist peim. Dað er margt í skipulagi leikskóla sem styður slíka upplifun, bæði er víða sjónrænt dagskipulag haft uppi við eða farið er yfir pað í samverustundum. Flestir leikskóladagar markast af atriðum sem eru eins dag frá degi, eins og matartímar, samverustundir og útivera. Dau mynda einhvers konar takt eða hrynjanda yfir daginn sem festist í minni barna, verða að vaðsteinum í daglegu starfi, en gefa börnum tilfinningu fyrir röð atburða og próa með peim tímaskyn (Friedman, 1990; Heidegger, 1924/1992, 1927/1962). Samkvæmt pessu er ljóst að tímaskyn barna er ekki háð eða bundið klukku. Fram kom í samtölum við börnin að pau kunnu almennt ekki að nota klukku. Dau pekkja hins vegar klukkur og átta sig á pví til hvers pær eru notaðar, til að mæla tíma. Prátt fyrir að kunna ekki á klukku áttu börnin ekki í erfiðleikum með að teikna pær. Pau sem teiknuðu klukku teiknuðu mörg einnig tölustafina og gátu sett tölur tilviljanakennt á skífuna. Ljóst er að skilningur peirra á klukkunni er einstaklingsbundinn. Er pað í samræmi við pað sem bent hefur verið á að börn á leikskólaaldri hafa oft takmarkaða kunnáttu á klukku og tekur oft langan tíma fyrir pau að yfirfæra reynslu sína og pekkingu á tíma yfir á mælingu klukkunnar (Harner, 1982; Levin, 1992; Piaget, 1969; Pouthas, 1993). Skýrt dæmi um slíkt er pegar drengur sagðist koma í leikskólann klukkan tólf en vera sóttur klukkan hundrað eða fimmtán.

Pacini-Ketchabaw (2012) ræðir um „ofríki klukkunnar“ og á par við hversu mikið klukkan mótar starfshætti í leikskólum og tíma barna í daglegu starfi. Degar litið er á sjónrænt skipulag leikskóla par sem deginum er skipt upp í allt að 19 mismunandi atburði er ljóst að klukkan ræður för. Börnin virðast ekki kippa sér upp við fjölda atriða í skipulagi og geta áttað sig á röð peirra eins og dæmið sýnir um stúlku sem leit á skipulagið og veitti strax eftirtekt að pað vantaði matmálstímann á sjónræna skipulagið.

Ef litið er til pess að börnin skynja tíma sem röð atburða fremur en eftir tímamælingu klukkunnar er áhugavert að velta fyrir sér hvernig pau skynja tíma peirra atburða sem pau upplifa. Баð, að eitthvað gat tekið langan tíma, gat bæði verið merki um að atburðurinn væri skemmtilegur eða leiðinlegur. Ef atburðurinn var í flæði eins og leikur eða skemmtilegt spil gat barnið upplifað að pað tæki langan tíma, en atburður gat einnig tekið langan tíma ef/pegar börnunum leiddist eða pau voru að bíða eftir einhverju, eins og strætó. Fleiri dæmi styðja pað að biðtími var lengi að líða, til dæmis að syngja matarlagið sem oft er sungið meðan beðið er eftir matnum. Dessi upplifun barnanna á tíma fannst rannsakendum einstaklega áhugaverð og hefðu gjarnan viljað skoða betur, sérstaklega í ljósi aðstæðna sem börnin hafa litla stjórn á.

Tímaskyn barna í pessari rannsókn einkenndist iðulega af einhvers konar núvitund og mætti segja að tímaskyn peirra sé afstætt og bundið aðstæðum. Er pað í samræmi við niðurstöður annarra sambærilegra rannsókna sem sýna margradda tímaskyn (Katsuura o.fl., 2021; Nomura and Matsuno, 2016). Í samtölum rannsakenda við börnin kom fram að peim fannst dagurinn fljóta vel og viðfangsefni dagsins vera fjölbreytt og skemmtileg. Almennt fannst peim pau ekki purfa að bíða lengi eða flýta sér og fannst pau til dæmis yfirleitt vera fljót að klæða sig í útifötin áður en pau fara út. Tíminn var fljótur að líða pegar pau voru að leika sér. Nokkur nefndu að peim fyndist erfitt í samverustund og í hvíld, par sem pau töldu sig ekki purfa að hvíla sig. Gæti pað stafað af pví að pau hafi lítið um pær stundir að ráða (Wood, 2013). Annars var greinilegt að börnunum fannst pau hafa úr fjölbreyttum viðfangsefnum að velja í leikskólanum og styður pað við niðurstöður 
annarra rannsókna sem bent hafa á mikilvægi fjölbreyttra viðfangsefna í leikskólum (Kristín Karlsdóttir og Anna Magnea Hreinsdóttir, 2016; Mennta- og menningarmálaráðuneytið, 2011). Kannski má segja að petta frelsi og val speglist vel í orðum drengsins sem sagðist byrja daginn á að finna sér eitthvað að gera.

Рað má sjá mun á gögnum eftir skipulagi leikskóla og að börn í leikskólum par sem áhersla er á leik og flæði höfðu víða fjölbreyttari tækifæri til að velja sér leik. Par með er ekki sagt að leikur hafi ekki einkennt pá skóla sem meiri festa var í dagskipulagi. Davies og félagar (2013) hafa bent á að langur samfelldur tími til leiks sé börnum mikilvægur til að pau geti bæði upplifað flæði og fengið svigrúm til að sökkva sér í leik án tímapressu. Erlendis hafa hugmyndir um „hæga uppeldisfræði“ skotið upp kollinum, sem byggja á að börnin fái tækifæri til að kafa í viðfangsefni í langan tíma í samstarfi við önnur börn og kennara (Clark, 2020). Velta má fyrir sér hvort slík hugmyndafræði gæti rúmast innan pess sem við köllum hefðbundið dagskipulag. Má pá benda á skrif Vintimilla og Pacini-Ketchabaw (2020) um hættuna á að dagskipulagið pjóni ekki raunverulegum pörfum barna, pau upplifi ekki merkingarbæra reynslu, en verði pess í stað viðtakendur pekkingar. Баð kom pví ekki á óvart að heyra börnin segja að peim pætti pau vera lengi í leikskólanum. Dað sem kom helst á óvart var að heyra pau segja pað á pann hátt að pað væri ekki endilega erfitt eða аð раð ylli peim vanlíðan. Deim fannst yfirleitt mjög skemmtilegt í leikskólanum og ekki bar á öðru en að peim liði almennt vel.

Niðurstöður pessarar rannsóknar styðja einnig við aðrar rannsóknir sem sýna að vinátta barna, félagar peirra og góð samskipti við pá, skipta börn miklu (Anna Magnea Hreinsdóttir, 2009, 2012; Corsaro, 2005; Jóhanna Einarsdóttir, 2008; Jóhanna Einarsdóttir og Sara M. Ólafsdóttir, 2020). Баð kom greinilega fram í samtölum við börnin að pau töldu sig eiga vini í leikskólanum og voru samskiptin við pá yfirleitt góð. Enda kom fram að pað versta sem gat komið fyrir í leikskólanum voru erfið samskipti, ,„að kýla og bíta“.

Par sem börnin pekkja ekki annað en að dvelja í leikskóla allan daginn er mikilvægt að leikskólastarf taki mið af sjónarmiðum peirra og pörfum og að leitað sé eftir röddum barna pegar leikskólastarf er skipulagt, enda er talið að raddir barna og sjónarmið séu helsta breytingaraflið í skólastarfi í framtíðinni. Skilaboð pessarar rannsóknar eru pau, að vinátta barna sé peim mikilvæg og að pau fái tækifæri til að fást við fjölbreytt viðfangsefni í leikskólanum sem börnin fá að stýra. Einnig að tímaskyni peirra sé gefinn gaumur og að dagskipulag leikskóla taki mið af skynjun barna á tíma, eða eins og skáldið Guðrún Eva Mínervudóttir (Kristjana B. Guðbrandsdóttir, 2018) sagði: „Gerðu færra, gerðu eitt í einu, gerðu pað hægar. Hafðu lengra bil á milli gjörða.“

Dakkir. Við viljum pakka lífsglöđum börnum og starfsfólki leikskóla sem tók einstaklega vel á móti okkur fyrir viðkynni og pátttöku í pessari rannsókn.

\section{Children's perspectives of their time spent in preschool}

The aim of this research was to give preschool children the opportunity to express their views on their daily life within the preschool and their experience of length of stay for the purpose of shedding light on what affects their well-being in preschool. The study took place in six preschools in the capital area in Iceland. It describes the views of the children participating in the research.

The theoretical background of the research relates to children's perception of time in the light of theories and research. Time is a series of activities that take place in our lives and can pass quickly or slowly, depending on our perception of it. This is especially true for children of preschool age who often do not know how to measure time by the clock, but rather by what they are doing. Time is an important factor in preschool activities, and a key element in any curriculum is the schedule or timetable. 
The preschool day is divided into events and activities such as mealtime, rest time and play time. These regular activities map out what happens during the day and must be based on children's perceptions of time with an emphasis on their rhythm, wellbeing, and learning. It is also important to consider what gives meaning to children in their daily lives, how they understand, interpret, and give meaning to the events of the day, subjects, and communication. The effects that time can have on the school's work are discussed, as well as research related to friendships and subjects.

The research is based on participatory research methods well suited to the aim of the research. When done in collaboration with children, they can provide insight into the world of children and increase adults' understanding of their views, for example about the length of their stay during the day in the preschool and what gives it meaning. Two types of daily schedule occurred, a very tight one with many different activities and a program with fewer activities with emphasis on flow throughout the day.

The results show that children understand the sequence of events well and have a sense of time. The organization of the preschools' daily schedule supports such an experience. In some preschools, the schedule was visual on the wall and reviewed during circle time, and most days were marked by things that did not change from day to day, such as mealtimes, circle time and outdoor activities. Those stepping stones form a kind of rhythm in the day, giving the children a sense of the sequence of events that helps them develop an understanding of time. According to this, children's time experience is not dependent on or tied to a clock, and they generally did not know how to use one. However, they knew clocks, and their purpose was clear to the children; to measure time.

The present characterized children's sense of time. It could be stated that their sense of time is relative and situational. Many children indicated that they thought the day was going well and that the day's activities were varied and fun. It was also clear that the children felt that they had various activities to choose from in the preschool.

The tyranny of the clock refers to how much the clock shapes practices in preschools and children's time there. When looking at visual schedules in some of the schools, it is clear how the clock determines the rhythm of the day. However, children in preschools which emphasize flow had a wider range of opportunities for continuous play. The claim is not that play did not characterize the preschool that focused on sequences of activities, but the time for play was usually shorter.

Considering that children perceive time as a sequence of events, it is interesting to consider how they perceive the time of the preschool activities. The fact that something could take a long time can signify that they enjoyed the experience or found it boring. If it was an activity that they experience as a flow like a play or one they enjoyed, they felt it took a long time. Still, some activities they felt took a long time were those where children felt limited by the environment, such as waiting for the bus.

Key words: Preschool, children's perspectives, meaning making, preschool practice 


\section{Um höfunda}

Anna Magnea Hreinsdóttir (amh@hi.is) lauk námi í tómstundafræðum frá Göteborgs folkhögskola í Svípjóð árið 1980, B.Ed.-gráđu í leikskólafræðum frá Kennaraháskóla Íslands árið 1999 og meistaraprófi frá sama skóla árið 2003. Árið 2009 lauk hún doktorsprófi í menntunarfræðum frá Menntavísindasviði Háskóla Íslands með áherslu á lýðræðislegt umræðumat á skólastarfi. Hún vann sem leikskólastjóri og leikskólafulltrúi á árunum 1991-2015 og var sviðsstjóri fjölskyldusviðs Borgarbyggðar á árunum 2015-2020. Nú starfar hún sem aðjúnkt við Menntavísindasvið Háskóla Íslands.

Kristín Dýrfjörð (dyr@unak.is) er dósent við kennaradeild Háskólans á Akureyri. Kristín starfaði sem leikskólastjóri í um áratug og var virk í félagsstörfum fyrir Félag leikskólakennara. Hún tók pátt í að rita síðustu tvær aðalnámskrár leikskóla. Rannsóknir hennar snúa að lýðræði í starfi leikskóla, skapandi starfi í leikskólum og áhrifum stefnumótunar og hugmyndafræði á leikskólastarf.

\section{About the authors}

Anna Magnea Hreinsdóttir (amh@hi.is) earned her degree in leisure studies from Göteborgs folkhögskola, Sweden, in 1980, a. B.Ed. degree in preschool studies from the Icelandic University of Education in 1999 and a master's degree from the same university in 2003. She completed her Ph.D. on democratic school evaluation from the University of Iceland, School of Education in 2009. She has worked as a preschool and primary school officer for many years and as a director of education and welfare. She now teaches at the University of Iceland, School of Education.

Kristín Dýrfjörð (dyr@unak.is) is an associate professor at the University of Akureyri, School of Humanities and Social Sciences, Faculty of Education. She has long-term experience as a preschool principal in Reykjavík, has worked for the teachers' union and taken part in the development of the national curriculum at the Ministry of Education, both before and after taking up a position as a scholar in academia. Her research interests are: early childhood studies, democracy, policy studies and the connection between science and creativity in early childhood.

\section{Heimildir}

Akita, K. (2020). Prospects for a new narrative of childcare in Japan. Hattatsu, 162, 53-58.

Anna Elísa Hreiðarsdóttir og Kristín Dýrfjörð. (2019). Mat leikskólabarna á pátttöku í tilviksrannsókn. Sérrit Netlu 2019 - Menntun barna í leikskóla og á yngsta stigi í grunnskóla. http://netla.hi.is/serrit/2019/menntun_ barna_leik_grunn/02.pdf

Anna Magnea Hreinsdóttir. (2009). „Af pví að við erum börn“: Lýðræðislegt umræðumat á menntun barna og pjónustu fjögurra íslenskra leikskóla [doktorsritgerð, Háskóli Íslands]. Skemman. http://hdl.handle. net/1946/4331

Anna Magnea Hreinsdóttir. (2012). Hver hlustar? Raddir barna og áhrif peirra á leikskólastarf. Í Jóhanna Einarsdóttir og Bryndís Garðarsdóttir (ritstjórar), Raddir barna (bls. 75-99). RannUng; Háskólaútgáfan.

Arna H. Jónsdóttir, Bryndís Garðarsdóttir og Jóhanna Einarsdóttir. (2013). Leikskólabyrjun og lengd dvalartíma: Sjónarmið leikskólakennara og leiðbeinenda. Sérrit Netlu 2013 - Rannsóknir og skólastarf. http://netla. hi.is/serrit/2013/rannsoknir_og_skolastarf/001.pdf

Bottrill, G. (2018). Can I go E play now: Rethinking the early years. Sage.

Bruner, J. S. (1990). Acts of meaning. Harvard University Press. 
Clark, A. (2020). Towards a listening ECEC system. Í C. Cameron og P. Moss (ritstjórar), Transforming early education in England: Towards a democratic education (bls. 134-151). UCL Press.

Clark, A. og Moss, P. (2001). Listening to young children. National Children's Bureau; Rowntree Foundation.

Clark, A. og Moss, P. (2005). Spaces to play: More listening to young children using the Mosaic approach. National Children's Bureau.

Corsaro, W. A. (2003). We're friends, right? Inside kids' culture. Joseph Henry Press.

Corsaro, W. A. (2005). The sociology of childhood (2. útgáfa). Pine Forge Press.

Csikszentmihalyi, M. (1990). Flow. The psychology of optimal experience. Steps toward enhancing the quality of life. Harper Collins.

Csikszentmihalyi, M. (1997). Creativity. Flow and the psychology of discovery and invention. Harper Collins.

Dahlberg, G. og Moss, P. (2005). Ethics and politics in early childhood education. Routledge Falmer.

Davies, D., Jindal-Snape, D., Collier, C., Digby, R., Hay, R. og Howe, A. (2013). Creative learning environments in education - a systematic literature review. Thinking Skills and Creativity, 91, 80-91. https://doi.org/10.1016/j.tsc.2012.07.004

Dewey, J. (1938). Experience and education. Macmillan Press.

Dewey, J. (1943). The school and society. University of Chicago Press.

European Commission/EACEA/Eurydice. (2019). Key data on early childhood education and care in Europe - 2019 edition. Eurydice Report. https://publications.europa.eu/en/publication-detail/-/ publication/5816a817-b72a-11e9-9d01-01aa75ed71a1/language-en/format-PDF/source-102611557

Forman, H. (2015). Events and children's sense of time: A perspective on the origins of everyday timekeeping. Í Frontiers in Psychology, 6, 259. https://doi.org/10.3389\%2Ffpsyg.2015.00259

Formosinho, J. og Formosinho, J. (2016). Pedagogy in participation: The search for a holistic praxis. Í J. Formosinho og C. Pascal (ritstjórar), Assessment and evaluation for transformation in early childhood (bls. 26-55. EECERA; Routledge.

Foucault, M. (1977). Discipline and punish: The birth of the prison. Penguin Books.

Fraisse, P. (1963). The psychology of time. Harper and Row.

Friedman, W. J. (1990). Children's representations of the pattern of daily activities. Child Development, 61(5), 1399-1412. https://doi.org/10.2307/1130751

Graue, M. E. og Walsh, D. J. (1998). Studying children in context: Theories, methods, and ethics. Sage.

Groundwater-Smith, S., Dockett, S. og Bottrell, D. (2015). Participatory research with children and young people. Sage.

Guðrún Kristinsdóttir. (2017). Pátttaka barna í vísindarannsóknum. Almenn leiðsögn. Vísindasiðanefnd Háskóla Íslands.

Guðrún Kristinsdóttir og Hervör Alma Árnadóttir. (2015). Hliðvörður - hvert er hlutverk pitt? Dátttaka barna í rannsóknum. Netla - Veftímarit um uppeldi og menntun. http://netla.hi.is/greinar/2015/ryn/002. pdf

Hagstofa Íslands. (e.d.). Börn í leikskólum eftir aldri, lengd viðveru og rekstrarformi 1998-2020. https:// px.hagstofa.is/pxis/pxweb/is/Samfelag/Samfelag_skolamal_1_leikskolastig_0_lsNemendur/SKO01001. px/table/tableViewLayout1/?rxid=9097603c-5050-4727-aaca-6905b4487898

Harner, L. (1982). Talking about the past and the future. Í W. J. Friedman (ritstjóri), The developmental psychology of time (bls. 141-169). Academic Press.

Heidegger, M. (1962). Being and time (J. Macquarie og E. Robinson pýddu). SCM Press (frumútgáfa 1927).

Heidegger, M. (1992). The concept of time (W. McNeill pýddi). Blackwood (frumútgáfa 1924).

James, A., Jenks, C. og Prout, A. (1998). Theorizing childhood. Polity Press.

Jenks, C. (2005). Childhood. Routledge.

Jóhanna Einarsdóttir. (2008). Pátttaka barna. Í Bryndís Garðarsdóttir og Jóhanna Einarsdóttir (ritstjórar), Sjónarmið barna og lýdraði í leikskólastarfi (bls. 115-130). Háskólaútgáfan; RannUng. 
Jóhanna Einarsdóttir og Sara M. Ólafsdóttir. (2020). Fullgildi í leikskóla: Sjónarmið barna og starfsfólks. Tímarit um uppeldi og menntun, 29(2), 113-131. https://doi.org/10.24270/tuuom.2020.29.6

Katsuura, M. Ueda, H. og Fujii, M. (2021). Exploring the narrative of an early childhood education and care teacher from the perspective of polyphonic time. Japanese Psychological Research, (rafræn birting). https://doi.org/10.1111/jpr.12388

Kristín Karlsdóttir og Anna Magnea Hreinsdóttir. (2016). Hugleiðingar um gildi rannsóknarinnar. Í Kristín Karlsdóttir og Anna Magnea Hreinsdóttir (ritstjórar), Leikum, larum, lifum. Námssvið leikskóla og grunnpettir menntunar (bls. 247-268). RannUng; Háskólaútgáfan.

Kristjana B. Guðbrandsdóttir. (2018). Guðrún Eva upplifði kulnun: Hvíld er heilagur réttur. Fréttablaðið. https://www.frettabladid.is/lifid/gurun-eva-upplifi-kulnun-hvild-er-heilagur-rettur/

Levin, I. (1992). The development of the concept of time in children: An integrative model. Í F. Macar, V. Pouthas og W. J. Friedman (ritstjórar), Time, action, and cognition: Toward bridging the gap (bls. 13-32). Kluver.

MacNaughton, G., Rolfe, S. og Siraj-Blatchford, I. (2010). Doing early childhood research: International perspectives on theory and practice (2. útgáfa). Open University Press.

Markström, A. og Halldén, G. (2009). Children's strategies for agency in preschool. Children E Society, 23(2), 112-122. https://doi.org/10.1111/j.1099-0860.2008.00161.x

Mauthner, M. (1997). Methodological aspects of collecting data from children: Lessons from three research projects. Children and Society, 11, 16-28.

Mennta- og menningarmálaráðuneytið. (2011). Aðalnámskrá leikskóla.

Moss, P. og Cameron, C. (2020). Conclusion: From the state we're in to what we want for our children? Í C. Cameron og P. Moss (ritstjórar), Transforming early childhood in England: Towards a democratic education (bls. 220-239). UCL Press.

Nelson, K. (1986). Event knowledge: Structure and function in development. Erlbaum.

Nelson, K. og Gruendel, J. M. (1981). Generalized event representations: Basic building blocks of cognitive development. Í M. E. Lamb og A. L. Brown (ritstjórar), Advances in developmental psychology, I (bls. 131-158). Erlbaum.

Nomura, N. (2010). Narrative, time, and communication. Tomishobo.

Nomura, N. og Matsuno, K. (2016). Synchronicity as time: E-series time for living formations. Cybernetics and Human Knowing, 23, 69-77.

Pacini-Ketchabaw, V. (2012). Acting with the clock: Clocking practices in early childhood. Contemporary Issues in Early Childhood, 13(2),154-160. https://doi.org/10.2304\%2Fciec.2012.13.2.154

Pascal, C. og Bertram, T. (2009). Listening to young citizens: The struggle to make real a participatory paradigm in research with young children. European Early Childhood Education Research Journal, 17(2), 249-262. https://doi.org/10.1080/13502930902951486

Piaget, J. (1969). The child's conception of time. Ballantine Books.

Pouthas, V. (1993). Ontogenesis of temporal learning in the child experimental evidence and perspectives. Psychologica Belgica, 33(2), 171-183.

Samningur Sameinuðu pjóðanna um réttindi barnsins. (1992). https://www.althingi.is/lagas/150b/1992018.2c5. html

Sara Margrét Ólafsdóttir. (2013). „Dað skapar velliðan að purfa ekki að keppa við tímann“: Áhrif skipulags á velliðan barna i leikskóla [meistararitgerð, Háskóli Íslands]. Skemman. http://hdl.handle.net/1946/16816

Sargent, J. Q., Zacks, J. M., Hambrick, D. Z., Zacks, R. T., Kurby, C. A. og Bailey, H. R. (2013). Event segmentation ability uniquely predicts event memory. Cognition, 129(2), 241-255. https://doi. org/10.1016/j.cognition.2013.07.002

Van Manen, M. og Levering, B. (1996). Childhood's secrets: Intimacy, privacy and the self-reconsidered. Teachers College Press. 
Vintimilla, C. D. og Pacini-Ketchabaw, V. (2020). Weaving pedagogy in early childhood education: On openings and their foreclosure. European Early Childhood Education Research Journal, 28(5), 628-641, https://doi.org/10.1080/1350293X.2020.1817235

Wood, E. (2013). Play, learning and the early childhood curriculum (3. útgáfa). Sage.

Wood, E. (2018). Listening to young children: Multiple voices, meanings, and understandings. Í G. Goodliff, N. Canning, J. Parry og L. Miller (ritstjórar), Young children's play and creativity (bls. 150-162). Routledge.

Zacks, J. M., Speer, N. K., Swallow, K. M., Braver, T. S. og Reynolds, J. M. (2007). Event perception: A mind-brain perspective. Psychological Bulletin, 133(2), 273-293. https://doi.org/10.1037/00332909.133.2.273

Anna Magnea Hreinsdóttir og Kristín Dýrfjörð. (2021).

Upplifun barna af leikskóladvöl „Stundum er maður lengi í leikskólanum, en ekki alltaf“

Netla - Veftímarit um uppeldi og menntun. Menntavísindasvið Háskóla Íslands.

Sótt af http://netla.hi.is/greinar/2021/alm/12

DOI: https://doi.org/10.24270/netla.2021.12 